\section{ПРОМЫСЛОВО-ГЕОФИЗИЧЕСКОЕ РАЙОНИРОВАНИЕ ТЕРРИТОРИИ САРАТОВСКОЙ ОБЛАСТИ}

\section{К.Б. Головин, Б.А. Головин, М.В. Калинникова}

Саратовский государственный университет, кафедра геофизики

E-mail: Kalinnikova1@rambler.ru

В работе для нужд промысловой геофизики предлагается схема районирования Саратовской области, основанная на глубинах залегания и литологическом составе основных нефтегазоносных комплексов, тектоническом районировании территории, распространении соленосных отложений и зон развития аномально высоких пластовых давлений (АВПД), результатах замеров геофизических параметров в скважинах, стратиграфических разбивках, данных о конструкциях скважин, пластовых температурах и давлениях, минерализациях пластовых вод. Выделены шесть зон, характеризующихся общностью условий проведения промысловогеофизических исследований, показан характер распределения выявленных месторождений углеводородов по предлагаемым элементам районирования и по основным нефтегазоносным комплексам в их пределах. Выделенные зоны охарактеризованы соотношением начальных суммарных ресурсов углеводородов. Геолого-технические условия проведения ГИС по элементам промыслово-геофизического районирования сведены в таблицу.

\section{Well Logging Zoning of Saratov Region}

\section{K.B. Golovin, B.A. Golovin, M.V. Kalinnikova}

In work for needs of the mine geophysics the outline of the Saratov oblast division into district is offered, it is based on the depths of bedding and litological structure of the basic oil and gas complexes, tectonic division into district of the territory, distribution of the saltmeasures and zones of development of the anomaly press, results of the metering of geophysical parameters in the chinks, stratigraphy layings out, data about the designs of the chinks, bed temperatures and pressure, mineralization of the bed of waters. Six zones are picked out which are described by a generality of conditions of conducting of mine geophysical researches, the character of distribution of the revealed hydrocarbon deposits connected with the offered elements of the division into district and with the basic oil and gas complexes in their limits is shown. The allocated zones are characterized by the correlation of initial total resources of the hydrocarbon deposits. The geology technical conditions logging with the elements of the mine geophysics division into district are shown in the table.

В тектоническом отношении юго-восточные земли Волго-Уральской нефтегазоносной провинции (НГП), занимаемые Саратовской областью, расположены в зоне сочленения таких крупных тектонических элементов, как Рязано-Саратовский мегапрогиб, Волго-Уральская антеклиза и Прикаспийская мегавпадина, которые, в свою очередь, имеют сложное геологическое строение и подразделяются на элементы подчиненного порядка (рисунок).

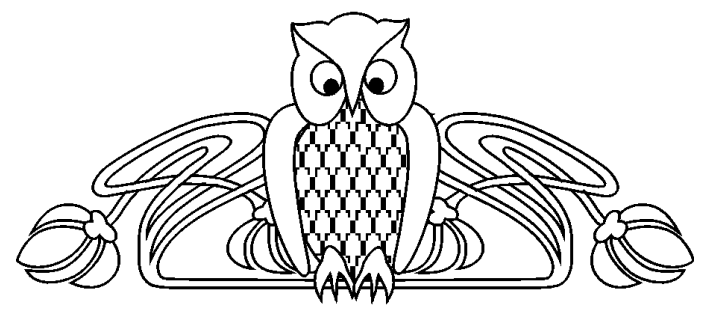

Разные части столь обширной территории характеризуются различным геологическим строением, включая литологический состав слагающих разрез пород, глубины залегания одновозрастных отложений, технические условия проведения геофизических исследований скважин (ГИС) и т.д. Общеизвестно, что характер применения и выбор конкретных методов ГИС зависит как от геолого-петрофизических, так и от технических характеристик изучаемого разреза.

Изучаемые коллекторы имеют как терригенный, так и карбонатный состав, нередко со значительными примесями глинистого материала. Терригенные коллекторы, так же как и карбонатные, не являются простыми по вещественному составу: первые, будучи преимущественно кварцевыми, в некоторых комплексах характеризуются олигомиктовым и полимиктовым составом минерального скелета; твердая фаза карбонатных коллекторов представлена известняками, доломитами, их смесями, нередко с примесями ангидритов.

Если терригенные коллекторы обладают преимущественно межзерновой структурой пустотного пространства, то емкость карбонатных обусловлена, помимо межзерновых пор, наличием трещин и каверн. Уже рассмотренные особенности требуют для определения литологического состава и различных составляющих пористости использования данных достаточно широкого комплекса ГИС.

Так, для разделения коллекторов на кварцевые и полимиктовые, а также для количественной оценки глинистости необходимы как минимум данные гамма-каротажа и метода потенциалов собственной поляризации. Определение минерального состава и пористости коллекторов требует привлечения данных так называемых «каротажей пористости».

Выделение коллекторов и оценка эффективных нефтегазонасыщенных толщин при разных геолого-технических условиях включает выявление признаков, свидетельствующих о подвижности пластового флюида по данным стандартных методов ГИС, и признаков, получаемых с помощью специальных исследований.

Еще одна важная процедура - оценка нефтегазонасыщенности коллекторов основывается на достоверной оценке удельного электрического сопротивления горной породы. Различные соотношения между электрическими сопротивлениями промывочной жидкости и ее фильтрата, с одной стороны, и пластовой воды - с другой, 

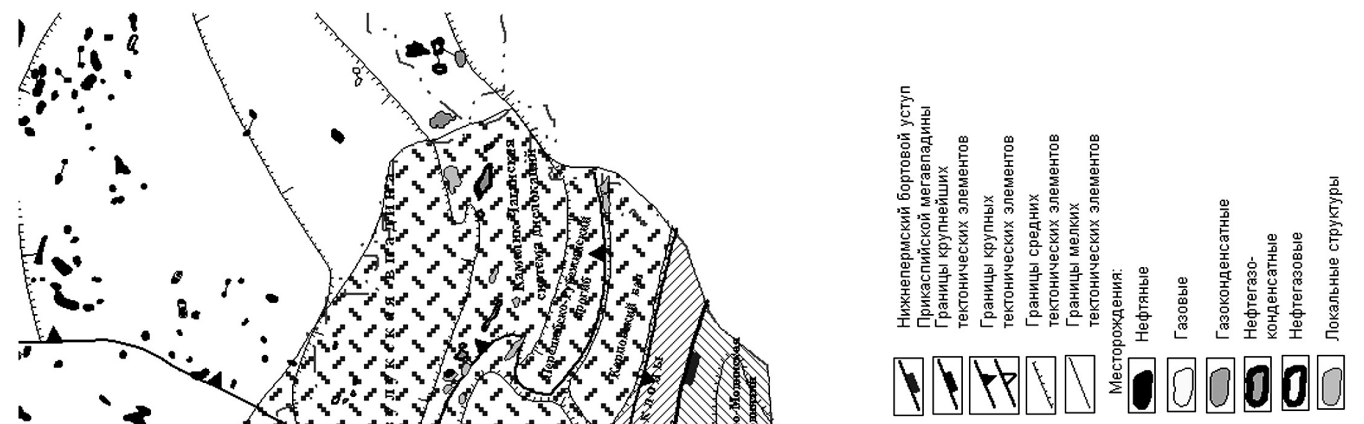

四

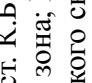

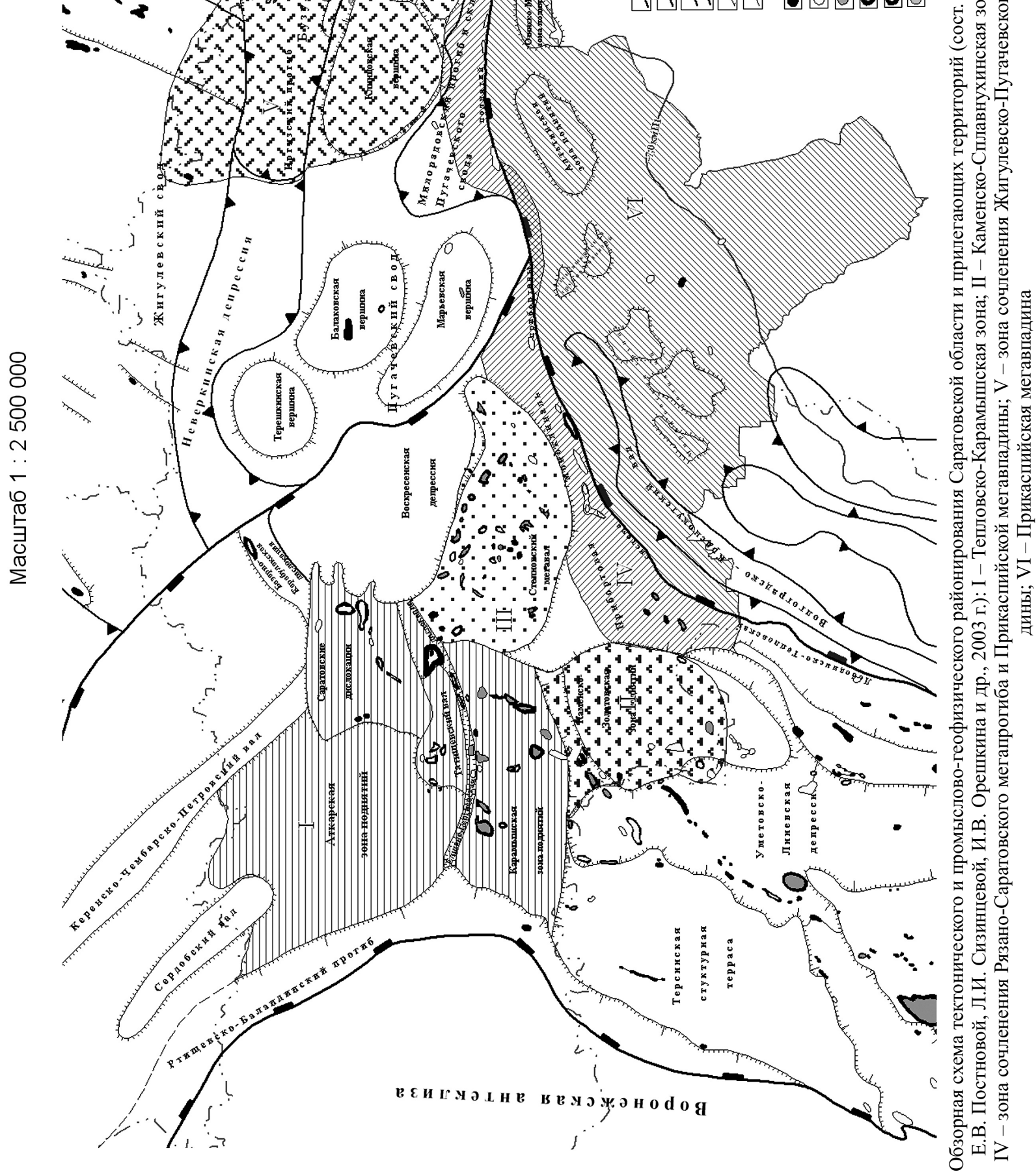


обусловливают повышающее либо понижающее проникновение фильтрата в коллектор. Преимущественное распространение получило повышающее проникновение. Однако в тех случаях, когда скважины вскрывают толщу соли, промывочная жидкость засолоняется, и характер проникновения изменяется на понижающее.

Геолого-технические характеристики разрезов (конструкции скважин, параметры промывочных жидкостей (ПЖ), минерализация пластовых вод, а следовательно, их удельное электрическое сопротивление (УЭС), температура пласта) также оказывают значительное влияние на результаты ГИС. Как правило, эти величины заметно изменяются с глубиной, которая, таким образом, является одним из основных параметром, определяющих их значения. Знание закономерностей изменения позволяет получить представление о характере проникновения фильтрата промывочной жидкости в пласт, учитывать температурные изменения сопротивления промывочной жидкости и пластовой воды. Кроме того, минерализация и УЭС пластовых вод являются важными петрофизическими константами, входящими в уравнения Арчи [1], и вместе с сопротивлением бурового раствора определяют эффективность применения некоторых геофизических методов.

В этой связи в настоящей работе предлагается районирование территории Саратовской области для выделения участков, характеризующихся однородностью предварительно заданного набора показателей, обеспечивающего дифференциацию геофизических и геолого-технических условий проведения ГИС.

В целом для региональной структуры исследуемого района характерно наличие регионального наклона в направлении Прикаспийской мегавпадины. Поверхность фундамента испытывает погружение от абсолютных отметок «-1000» м на западе и «-2000» м на севере до «-4000»- «-6000» м на юге- юго-востоке. В пределах Прикаспийской мегавпадины поверхность фундамента наклонена к ее центру от «-6000» м до «-21000» м (Н.В. Грекова, Д.Л. Федоров, Н.В. Неволин, 1986 г.).

На фоне регионального наклона на юго-восток на отдельных территориях отмечается несовпадение структурных планов для различных горизонтов осадочного чехла (ОЧ). В этом отношении наиболее характерны северо-западная и юго-восточная части Рязано-Саратовского мегапрогиба, являющиеся наиболее подвижными зонами, начиная с рифейского этапа тектогенеза [2-4]. Более простые условия залегания и общее соответствие структурных планов различных горизонтов характерны для районов Волго-Уральской антеклизы. Наиболее резкие изменения структурных планов тектонических элементов чаще всего отмечаются на уровне подошвы среднефранских отложений, называемой также «подошвой карбонатного девона». Наличие крупного углового стратиг- рафического несогласия в отложениях верхнего девона дает основание некоторым исследователям [5] выделять в палеозойско-кайнозойской части осадочного чехла по крайней мере два основных структурных этажа: нижний, охватывающий нижнюю часть отложений осадочного комплекса до нижнефранского подъяруса включительно и в общих чертах повторяющий строение поверхности дорифейского фундамента, и верхний, объединяющий карбонатный комплекс пород верхнего девона, каменноугольные, пермские, мезозойские и палеогеновые отложения. В Прикаспийской нефтегазоносной провинции вследствие ее сложного геологического строения и увеличенных толщин отложений деление более дробное: выделяются несколько подсолевых и надсолевых структурных этажей (Н.И. Ускова, Н.В. Грекова, П.М. Быстрицкая, 1974 г.).

В нижнем структурном этаже в пределах территории исследования выделяются юго-восточная часть Рязано-Саратовского мегапрогиба, юго-западная часть Волго-Уральской антеклизы и северная часть Прикаспийской мегавпадины.

Рязано-Саратовский мегапрогиб занимает почти всю западную часть исследуемой территории. Это древнейшая надпорядковая структура, начало формирования которой относится к протерозойскому времени (Пачелмско-Саратовский авлакоген). Для него характерно дискретное строение, т.е. наличие выступов, грабенов, систем разломов и флексур. В пределах мегапрогиба выделяются структуры более мелкого порядка (см. рисунок), наиболее значимыми из которых с точки зрения наличия скоплений нефти и газа являются Степновский мегавал, Саратовские дислокации, Татищевский вал, Елшано-Сергиевская дислокация, Карамышская депрессия, КаменскоЗолотовская приподнятая зона и Иловлинско-Родниковская дислокация.

В пределах Волго-Уральской антеклизы, имеющей относительно более простые условия залегания по сравнению с Рязано-Саратовским мегапрогибом, выделяются осложняющие ее тектонические элементы первого и второго порядков, такие как Пугачевский и Жигулевский своды, Бузулукская впадина, Иргизский прогиб и др. (см. рисунок). В палеозойских отложениях перечисленных структурных зон расположены многочисленные месторождения углеводородов.

Ряд месторождений приурочен к зоне сочленения Рязано-Саратовского мегапрогиба и ВолгоУральской антеклизы с Прикаспийской мегавпадиной, называемой прибортовой моноклиналью.

Выше уже говорилось о том, что технические характеристики разрезов (конструкции скважин, параметры промывочных жидкостей, минерализация пластовых вод, а следовательно, их удельное электрическое сопротивление (УЭС), температура пласта) также оказывают значительное влияние на результаты ГИС. 
При обсадке скважин, как правило, используется многоколонная конструкция. Бурение начинают большим диаметром (400-500 мм), затем, по мере увеличения глубины, диаметр сужают, и основные нефтегазоносные комплексы проходят с диаметром от 290 до 190 мм (в основном 216 мм), иногда 161 мм. При этом каждый участок равного диаметра обсаживается соответствующей колонной.

Наиболее сложные конструкции (5-6 колонн) используются при бурении скважин на каменноугольные и девонские объекты в зоне сочленения Рязано-Саратовского мегапрогиба и Прикаспийской мегавпадины, где помимо большой глубины залегания отложений и наличия АВПД осложняющим фактором является присутствие в разрезе мощной соленосной толщи, проходка которой практически невозможна без постоянного перекрытия обсадной колонной. При бурении скважин на нижнепермские объекты применяются более простые, 2 - 3-колонные конструкции.

Возможность использования наиболее простых конструкций скважин появляется в Тепловско-Карамышской зоне, небольшая глубина залегания поисковых объектов которой (до 1 км) и отсутствие осложнений при бурении позволяют осуществлять проходку от устья до забоя долотом одного диаметра.

Относительно небольшой диаметр скважин в продуктивных комплексах благоприятствует проведению исследований, поскольку влияние скважины на показания геофизических методов не выходит за допустимые пределы и может быть легко учтено существующими палетками.

Сравнительный анализ УЭС разных типов буровых растворов, используемых при бурении скважин в каждой из пяти зон, выделенных на исследуемой территории, показывает, что буровые растворы, применяемые в зоне сочленения Рязано-Саратовского мегапрогиба и Прикаспийской мегавпадины и в зоне сочленения Жигулевско-Пугачевского свода и Бузулукской впадины, характеризуются пониженными значениями УЭС (в среднем 0,27 и 0,40 Ом - м соответственно) по сравнению с Тепловско-Карамышской зоной $(0,87$ Ом $\cdot$ м), Степновской зоной $(0,71 \mathrm{Oм} \cdot \mathrm{M})$ и Каменско-Сплавнухинской зоной $(0,56$ Ом · м). Это обусловлено тем, что в пределах бортовой зоны Прикаспийской мегавпадины и юго-западной части Бузулукской впадины широко распространены пермские соленосные отложения, отсутствующие на остальной рассматриваемой территории, что естественным образом отражается на минерализации (а следовательно, и сопротивлении) промывочной жидкости.

Диапазон изменения УЭС применяемых буровых растворов находится в пределах 0,051,4 Ом · м, однако преобладают относительно пресные буровые растворы с УЭС, превышающим 0,2 Ом · м при температуре пласта. Соответственно преимущественным типом проникновения фильтрата бурового раствора оказывается повышающее, особенно в водонасыщенных пластах, что является практически необходимым (но недостаточным) признаком обводненности.

На основе анализа зависимостей температуры от глубины, установленных для скважин юговостока Русской плиты, подтверждено последовательное и закономерное увеличение температуры с ростом глубины залегания отложений. В связи с этим, учитывая общее погружение отложений в направлении с северо-запада на юго-восток, можно сделать вывод о закономерном увеличении температуры в породах одного и того же возраста в данном направлении. При этом интенсивность увеличения температуры с ростом глубины подвержена значительным колебаниям. Однако сами значения температур в разных зонах на одинаковых глубинах изменяются в достаточно узких пределах, что дает основание принять для всех зон единую зависимость температуры от глубины.

Для пластовых давлений изучаемой территории также отмечается закономерное их увеличение с ростом глубины залегания отложений. Тем не менее, начиная с глубины 3500 м, отмечается нарушение тесной корреляционной связи, обусловленное развитием в бортовой зоне Прикаспийской мегавпадины зон с аномально-высокими пластовыми давлениями.

Диапазоны изменения пластовых температур и давлений, присущие разным зонам, приведены в таблице.

Воды средне-верхнедевонского НГК относятся к минерализованным рассолам. Наиболее высокоминерализованные воды встречены в районе зоны сочленения Жигулевско- Пугачевского свода и Бузулукской впадины. Так, на Рахмановской площади на глубине 2000 м в отложениях живетского яруса обнаружены воды с минерализацией около 280 г/л.

Для вод данного комплекса отмечается последовательное и закономерное увеличение общей минерализации с северо-запада на юго-восток в соответствии с общим увеличением глубин залегания водоносных горизонтов от 169 г/л (НовоЗахаркинская площадь) до 260 г/л (Рахмановская площадь) [6].

В то же время на больших глубинах в северо-западной зоне сочленения Рязано-Саратовского мегапрогиба и Прикаспийской мегавпадины встречены значительно опресненные подземные воды различных генетических типов, характеризующиеся минерализацией до 65-110 г/л [7]. Как правило, относительно маломинерализованные воды приурочены к глубинам порядка 3500-4000 м. К ним относятся воды отдельных участков девонских, в основном терригенных отложений.

Воды верхнедевонско-нижнекаменноугольного комплекса высокоминерализованные, с суммой солей до 282 г/л. Как и для предыдущего комплекса, для вод «карбонатного» девона от- 


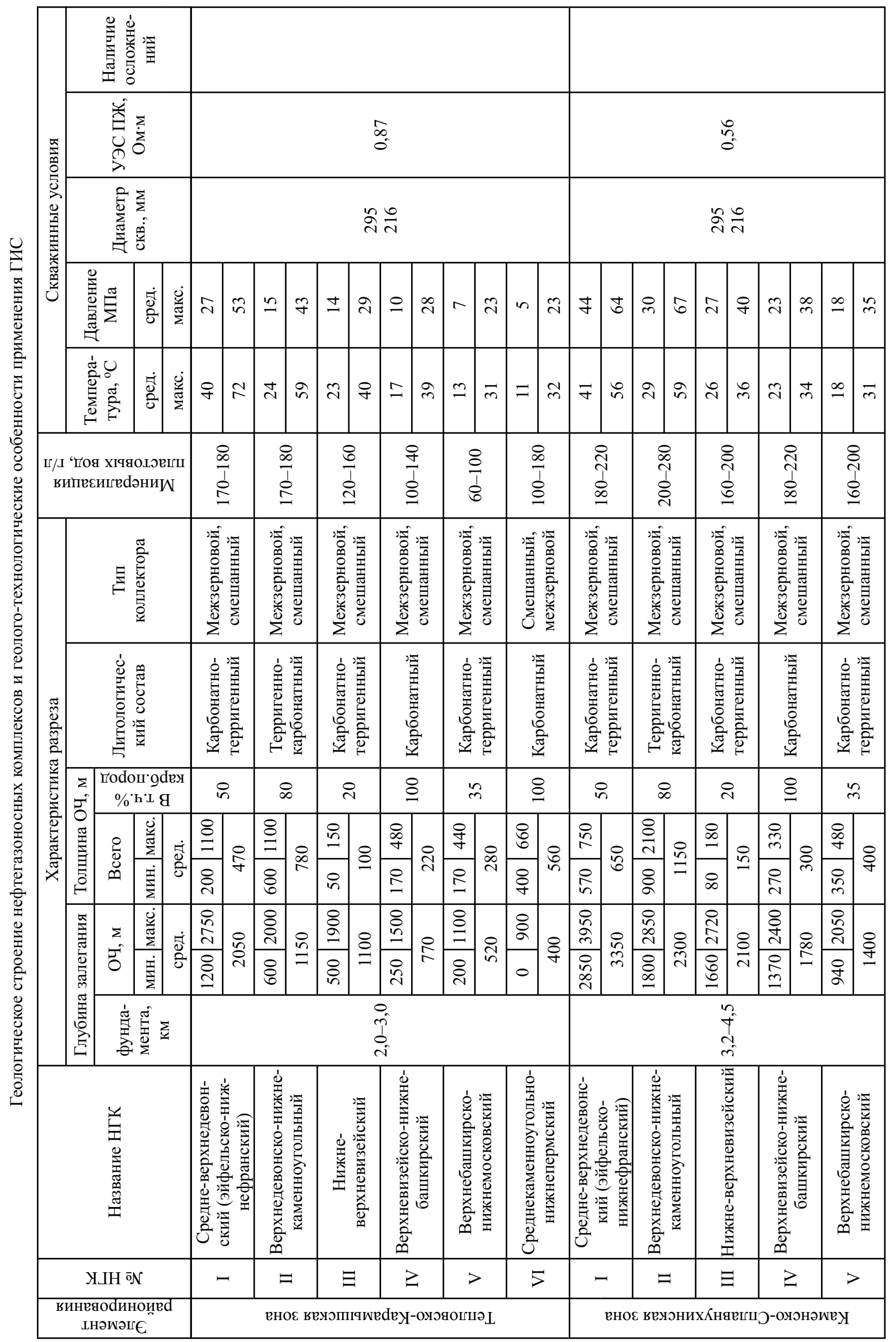




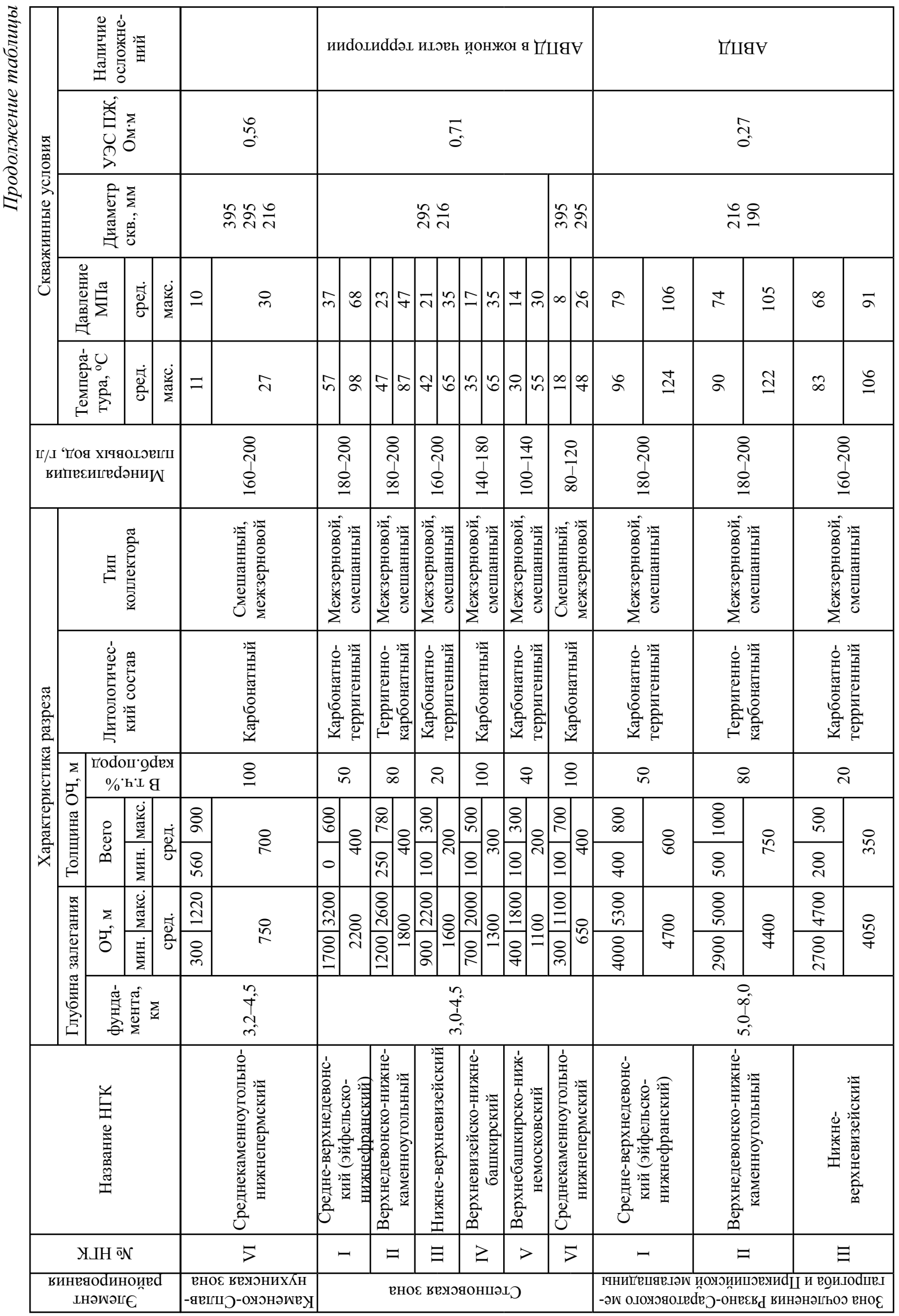




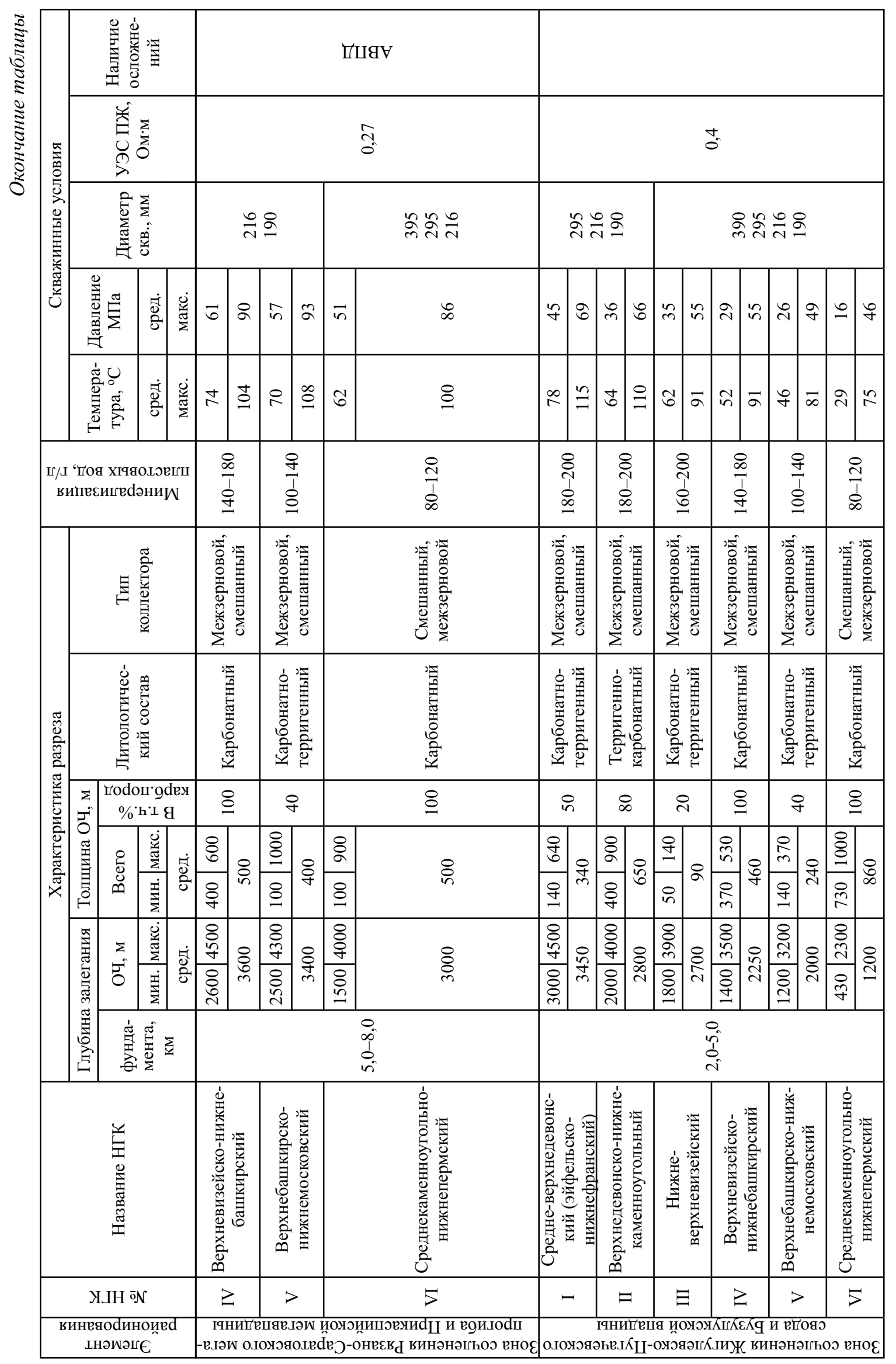


мечается закономерный характер увеличения общей минерализации вод с северо-запада на юго-восток. Кроме того, четко намечается увеличение минерализации и с севера на юг, примерно до Каменской площади, где сумма солей в водах достигает 282 г/л.

Так же как и для вод предыдущего комплекса, в северо-западном обрамлении Прикаспийской мегавпадины встречаются зоны опреснения подземных вод. Так, в радаевско-косьвинских отложениях скв. 6 Ждановской на глубине 4331 м отмечена минерализация пластовых вод 99,7 г/л, тогда как «нормальное» значение для данной территории составляет 200-220 г/л.

В соответствии с изменением глубины залегания водоносных горизонтов в различных частях региона минерализация пластовых вод третьего, нижне-верхневизейского терригенного комплекса колеблется в широких пределах 120-265 г/л. Так же как и в предыдущих двух, в этом комплексе наблюдается равномерное увеличение минерализации вод в направлении с северо-запада на юго-восток.

Минерализация пластовых вод верхневизейско-нижнебашкирского карбонатного комплекса в зависимости от глубины залегания колеблется в широких пределах от 100 до 224 г/л.

Наиболее высокоминерализованные воды вскрыты в Каменско-Сплавнухинской зоне на Каменской и Топовской площадях, а также в районе зоны сочленения Жигулевско-Пугачевского свода и Бузулукской впадины на Рахмановской площади. Изменение минерализации вод рассматриваемого комплекса в региональном плане носит тот же характер закономерного увеличения с севера на юг и на восток, что и у всех ранее рассмотренных комплексов.

Для пластовых вод верхнебашкирско-нижнемосковского терригенного комплекса характерна минерализация 52-196 г/л. Максимально минерализованные воды приурочены к Каменско-Сплавнухинской зоне. Все отмеченные для предыдущих комплексов принципиальные закономерности в распределении минерализации вод полностью сохраняются.

В среднекаменноугольно-нижнепермском карбонатном комплексе наиболее высокоминерализованные воды с суммой солей 168-195 г/л обнаружены на Каменской и Некрасовской площадях. Здесь происходит увеличение минерализации с севера на юг.

В двух последних комплексах в северо-западном обрамлении Прикаспийской мегавпадины встречаются зоны опреснения подземных вод.

Например, в подольско-каширских отложениях скв. 5 Карпенской на глубине 2900-2910 м сумма солей в пластовых водах равна 94 г/л, в то время как «нормальное» значение для данной глубины этой территории составляет 200 г/л.

Таким образом, для минерализации пластовых вод исследуемой территории существуют две закономерности:
1) в региональном плане происходит равномерное увеличение минерализации в направлении с северо-запада на юго-восток;

2) главным фактором, контролирующим минерализацию пластовых вод, является глубина залегания отложений. И хотя можно говорить о региональном распространении опресненных вод в глубоко залегающих горизонтах почти по всему периметру обрамления Прикаспийской мегавпадины, общая закономерность заключается в нарастании минерализации с глубиной независимо от того, в какой зоне это возрастание имеет место.

Изучив картографический материал (структурные карты по кровлям основных НГК, схему тектонического районирования территории, схему распространения соленосных отложений и зон развития АВПД и каротажный материал, а также проанализировав результаты скважинных замеров температур, давлений и минерализаций пластовых вод, мы сделали выводы, позволяющие осуществить промыслово-геофизическое районирование территории (см. таблицу)).

На основании перечисленных признаков правобережная часть Рязано-Саратовского мегапрогиба разделена на две зоны, включающие в себя элементы тектоники второго и третьего порядков. К первой зоне, условно названной «ТепловскоКарамышской», отнесены Саратовские дислокации, Татищевский вал, Елшано-Сергиевская дислокация и Карамышская депрессия. Вторая, «Каменско-Сплавнухинская зона», включает в себя Каменско-Золотовскую приподнятую зону и Уметовско-Линевскую депрессию. Выделение этой зоны обусловлено не только приведенными в таблице признаками, но и специфическими условиями осадконакопления, проявляющимися в присутствии здесь отложений волгоградского горизонта [8], дефиците фаунистического материала, контрастной латеральной литологической изменчивости одновозрастных отложений, монотонности литологического состава карбонатных толщ, нарушении стратиграфической приуроченности глинизации в разрезах, наличии глинистой толщи в отложениях «терригенного девона» и предельно затрудняющими корреляцию разрезов по материалам ГИС.

В левобережной части юго-востока РязаноСаратовского мегапрогиба расположена третья зона районирования - «Степновская», в основном совпадающая с одноименным мегавалом.

Следующая зона, в которой отмечается повышенное скопление месторождений УВ, приурочена к Волго-Уральской антеклизе, к юго-западной части Бузулукской впадины и носит название «зона сочленения Жигулевско-Пугачевского свода и Бузулукской впадины».

Пятый элемент предлагаемого нами геологотектонического районирования в тектоническом плане соответствует зоне сочленения Рязано-Саратовского мегапрогиба и Волго-Уральской антек- 
лизы с Прикаспийской мегавпадиной, приурочен к Прибортовой моноклинали и южным склонам Пугачевского свода и носит название «зона сочленения Рязано-Саратовского мегапрогиба и Прикаспийской мегавпадины».

Шестая зона - собственно Прикаспийская мегавпадина - в системе нефтегазогеологического районирования относится к Прикаспийской нефтегазоносной провинции (ПНГП) и по своему геологическому строению существенно отличается от всех вышеописанных зон. Кроме того, даже в пределах самой мегавпадины выделяются участки с принципиально разным геологическим строением. В целом этому элементу районирования присущи значительно увеличенные глубины залегания фундамента и основных отражающих горизонтов, наличие в разрезе многокилометровых толщ соленосных отложений, развитие зон аномально высоких пластовых давлений, солянокупольная тектоника и пр. Из-за практического отсутствия данных и крайне низкой изученности, обусловленных в первую очередь исключительной сложностью строения, эта территория характеризуется минимальной достоверностью существующих структурных построений и наименьшей обоснованностью геологических моделей.

На основе выполненного районирования территории представилось возможным распределить месторождения углеводорода не только по содержащим их нефтегазоносным комплексам, но и по геолого-технологическим особенностям проведения ГИС, определив, таким образом, для более чем 100 продуктивных площадей принадлежность к определенной зоне. Большинство месторождений УВ приурочено к Степновской (35\%) и Тепловско-Карамышской зонам (34\%). При этом на долю Тепловско-Карамышской зоны приходится наибольшая база начальных суммарных ресурсов углеводородов исследуемой территории (29 \%), второе место занимает зона сочленения Жигулевско-Пугачевского свода и Бузулукской впадины (27\%), третье принадлежит зоне сочленения Рязано-Саратовского мегапрогиба и Прикаспийской мегавпадины - 20 \%. Для Степновской зоны, как и для зоны сочленения Жигулевско-Пугачевского свода и Бузулукской впадины, основным нефтегазоносным комплексом, содержащим 48-50 \% месторождений, является средне-верхнедевонский НГК, а для Тепловско-Карамышской зоны и зоны сочленения Рязано-Саратовского мегапрогиба и
Прикаспийской мегавпадины такими комплексами служат нижне-, верхневизейский (42\%) и среднекаменноугольно-нижнепермский (46\%) соответственно.

Таким образом, выделенные зоны охарактеризованы по ряду параметров, таких как погруженность поверхности кристаллического фундамента, глубины залегания и толщины основных НГК, литологический состав НГК, преобладающий тип коллектора, минерализация пластовых вод, скважинные условия; установлены качественные и количественные пределы изменения указанных параметров в отмеченных зонах; выявлены различия в наборе параметров для каждой зоны, позволяющие говорить о необходимости районирования для корректного решения геофизических (выбор оптимальных конструкций скважин и методов исследований) и геологических (прогнозирование геологического разреза и закономерностей развития коллекторов и их характеристик) задач.

\section{Библиографический список}

1. Дахнов В.Н. Интерпретация результатов геофизических исследований разрезов скважин. М., 1982. 448 с.

2. Грекова Н.В. Геоструктурные особенности юго-восточной части Пачелмско-Саратовского авлакогена в связи с оценкой перспектив нефтегазоносности: Автореф. дис. ... канд. геол.-минер. наук. Саратов, 1974.

3. Грекова Н.В. Тектоническое районирование Пачелмско-Саратовского авлакогена // Вопросы геологии Южного Урала и Поволжья. Саратов, 1975. Вып. 12. С. 59-67.

4. Козленко С.П., Кузнечова М.М., Кондратьева М.Г. и $\partial p$. Оценка перспектив нефтегазоносности Рязано-Саратовского прогиба. Саратов, 1970. $167 \mathrm{c}$.

5. Бражников Г.А., Кныр Л.Г. и др. Структурный план, история его развития и тектоническое районирование Волгоградской области. Волгоград, 1965. 186 с.

6. Федорова Т.И., Щекочихина В.М. Новое в стратиграфии девона Саратовского Поволжья // Советская геология. 1985. № 11. C. 68-69.

7. Зингер А.С. Газогидрохимические критерии оценки нефтегазоносности локальных структур // Тр. НВНИИГГ. 1966. Вып. V. С. 143-154.

8. Зингер А.С., Долгова Г.С., Федоров Д.Л. Генезис опресненных глубинных вод и кислых компонентов газов юговостока Русской платформы // Геология, методы поисков и разведки месторождений нефти и газа: Обзор ВИЭМС. M., 1980. C. 207-217. 